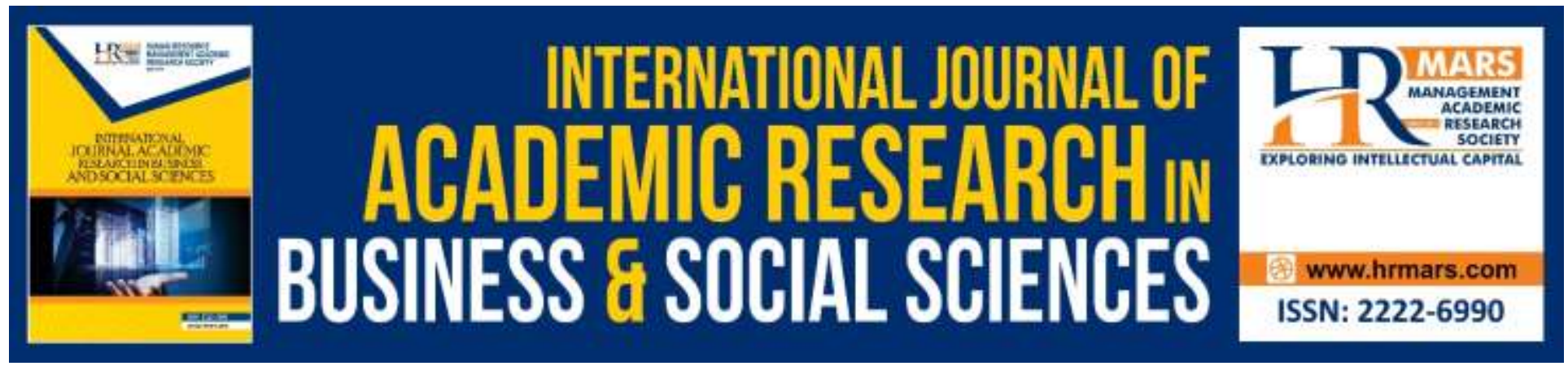

\title{
Symbolic Meaning of 'Tepung Tawar' in Deli Malay Traditional Marriage Ceremony in the City of Medan
}

Norsuhaily Abu Bakar, Rahmat Kartolo

To Link this Article: http://dx.doi.org/10.6007/IJARBSS/v9-i11/6609

DOI: 10.6007/IJARBSS/v9-i11/6609

Received: 06 October 2019, Revised: 28 October 2019, Accepted: 13 November 2019

Published Online: 30 November 2019

In-Text Citation: (Ling et al, 2019)

To Cite this Article: Bakar, N. A., Kartolo, R. (2019). Symbolic Meaning of 'Tepung Tawar' in Deli Malay Traditional Marriage Ceremony in the City of Medan. International Journal of Academic Research in Business and Social Sciences, 9(11), 907-913.

Copyright: (C) 2019 The Author(s)

Published by Human Resource Management Academic Research Society (www.hrmars.com)

This article is published under the Creative Commons Attribution (CC BY 4.0) license. Anyone may reproduce, distribute, translate and create derivative works of this article (for both commercial and non-commercial purposes), subject to full attribution to the original publication and authors. The full terms of this license may be seen at: http://creativecommons.org/licences/by/4.0/legalcode

Vol. 9, No. 11, 2019, Pg. 907 - 913

Full Terms \& Conditions of access and use can be found at http://hrmars.com/index.php/pages/detail/publication-ethics 


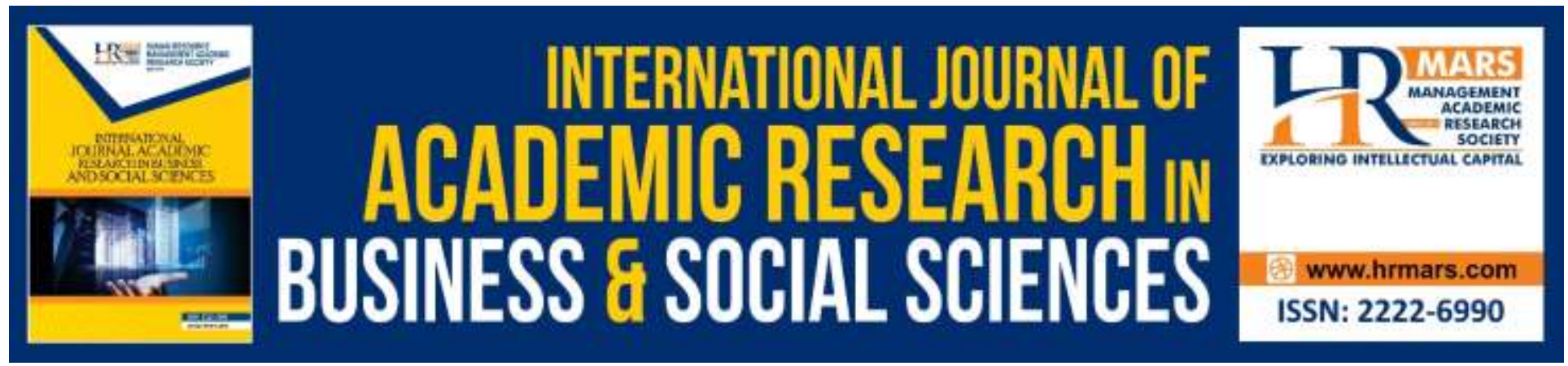

\title{
Symbolic Meaning of 'Tepung Tawar' in Deli Malay Traditional Marriage Ceremony in the City of Medan
}

\author{
Norsuhaily Abu Bakar, Rahmat Kartolo \\ Universiti Sultan Zainal Abidin, Kampus Gong Badak, 21300 Kuala Nerus, Terengganu. \\ Email: norsuhaily@unisza.edu.my
}

\begin{abstract}
The Clan marriage of Deli Malay in the city of Medan, Northern Sumatran Province evolves with the development of modern knowledge and technology. The development of modern knowledge and technology has paved a new mentality for the younger generation in which they no longer favour clan marriages of Deli Malay in the City of Medan, Northern Sumateran Province. This research aims to investigate on the symbolic meaning of 'tepung tawar' in the Deli Malay wedding ceremony held primarily in Medan. The results of this study indicate that a procession of 'tepung tawar' in Malay wedding ceremony Deli has a symbolic meaning in accordance with an understanding that is held by the society. The values contained therein reflect the patterns of life and the family system of Deli Malays. This research is one of the examination and reinforcement of the symbolic meaning that is present in the ceremonial marriage of Melayu Deli.
\end{abstract}

\section{Introduction}

The custom is an institution in our society which has a high value and are adhered to by the community. As an institution, the Malay's custom have been practiced by Deli Malays since centuries ago. Therefore, the Malay custom has a high value and norms obeyed by the Malay community. The behavior of the people are always regulated by the norms. For example, conversing with a courteous language is reflected in the norms of language, graceful walking steps are reflected with the norms in walking, organizing a wedding associated with the norms of marriage and so on.

The wedding ceremony and the makeup is discussed based on the idea that the Malay customs are not accurately defined and has not been prevalent several centuries ago. The Malay perspective is based on ethinic union or "cultural", not based on "genealogis" and apply relative regulations "Parental". The customs derived from the time of animism, Hinduism and Buddhism 
are adapted gradually by respecting the actions which are not forbidden by islam, so that the Malay culture became a part of the Islamic civilisation or "tamadun" (Luckman, 2005: 45)

The modernization of customs that are appropriate to the expansion of knowledge is not an obstacle. The custom itself is part of the science in community. Therefore, there are no prohibited branches. Although the custom should be tailored to the level of knowledge development, the community advocating the customs does not follow the development which caused them to be unsure and seemingly perceived against the reformation. The conflict does not occur when the advocates are amongst the intellectuals. In the present time, the clan members from Deli Malay consists of intellectual individuals which cause conflicts to no longer occur.

In nowadays ceremony, the VIP hails from the government officials, not the authority (Datuk or Tengku). Traditional ceremony has changed its function. Today's ceremony merely reminisce the identity and the glory of past societies. The leaders should preserve the custom by remaining a VIP in the traditional ceremony. Although they are not government officials, they remain wellrespected within the community. In accentuating the splendor of the customs, we should respect our leaders as way to uphold our own culture.

Etymologically, the symbol comes from the word Greece "sym-ballein" meaning to associate an (object, actions) with an idea (Hartoko \& Rahmanto, 1998) in (Sobur, 2004). It is also known as "symboois", which means a sign or hallmark that tells something to someone (Herusatoto, 2000) in (Sobur, 2004).

In human communication, symbol is an expression that represent or indicate something. One of the characteristics of symbol is that the symbol does not have a direct relationship with what it represents, thus it is fickle. The symbol can be in the form of sounds, a mark on the paper, and a way to give a specific meaning in interpersonal communication (Samovar, 2010; Maqbool, Ismail, Maqbool, \& Hassan, 2018).

The meaning is used to interpret surrounding events. Interpretation is the internal processes within us. We have to choose, check, store, classify and send the meaning according to the situation and depending on our actions. As such, we cannot communicate with others without them understanding meaning of the symbol that we use. Meaning is result of quality communication. Meaning is the result of our interaction with others (Morissan, 2013; Zulfadhli, 2018).

Constitutional changes resulted in a change in social status. Currently, the customs that are no longer bound and reflect the atmosphere of democracy which caused the difference in social status are not visible anymore. The preferred characteristic feature presently is the personality, 
INTERNATIONAL JOURNAL OF ACADEMIC RESEARCH IN BUSINESS AND SOCIAL SCIENCES

Vol. 9, No. 11, November, 2019, E-ISSN: 2222-6990 @ 2019 HRMARS

status and materialistic status of a person. Those who have the wealth can wear wedding material and equipment befitting a King or Sultan.

In fact, Deli Malay's wedding ceremony custom has symbolic meaning that are respected by the community.

\section{Symbols and Symbolic Meaning of 'Tepung Tawar' Performer}

$\mathrm{H}$. Buyung Bahib Aritonang said that the number of 'penepung tawar' cannot be even numbered. 'penepung tawar' numbers must be odd because according to the elders and leaders, evennumbered amount is not appropriate, in harmony with the teachings of Islam which prefers odd numbers. Malays hold Islamic teachings in the highest regard. In addition, according to the beliefs of the elders and leaders, even-numbered 'tepung tawar' will cause misfortune or in case of divorce after marriage.

$\mathrm{H}$. Buyung Bahib Aritonang also said that in addition to the odd numbers, the way the 'tepung tawar' traditional practice accompanied by specific chants also has its own purpose. Which brings a meaning, "a minimum amount of 'penepung tawar' is five people and most populous is 21 people. In the Malay phrase, ' even is less, odd is excesive '. In addition there is another expression mentioning that ' less follows custom, excessive follows Islamic law (syarak) '. The most frequent prayers during the ceremonies are barzanji and zikir. It is then completed with a prayer by a 'penepung tawar' which is also the 'Tuan Kadhi'.

Regarding the 'penepung tawar', Tenas Effendy also added that "the number of the guest who does 'penepung tawar' must be odd numbered, at least five people and the most populous is 21 people. The phrase, ' even is less, odd is excessive '. In another utterance ' less follows custom, excessive follows Islamic law (syarak) '.

\section{Tepung Tawar Ceremonial Process}

Hjh. Maslina Asniati says "the equipment from the 'penabur' have specific meaning, including: (a) lime talcum powder (commonly referred to as 'bedak sejuk'), which is traditionally made from rice flour that represents integrity, purity of heart and patience in marriage life, and can be mentioned with the phrase ' soothe the heart, protect the soul', whereas the purpose of the talcum powder and lime is ' powder removes envy, lime removes corruption'; (b) percung water (commonly referred to as mawar water), which is made from boiled fragrant leaves slices of lime scented leaves, which means upholding the family surname and clan dignity as brought up by the phrase 'uphold the name, bring honour; (c) 'beras basuh', namely the rice that was cleansed as much as possible, which means that the symbolic physical purity (Lahiriah) and purity of the soul (Batiniah) with the expression ' to wash all impurity, and cleanse all stench'; (d) turmeric rice, that is rice soaked with turmeric until it turns yellow and then dried, which means representing overflowing wealth (rezeki), nurtured and dignified as by the expressions ' overflowing wealth, timeless heritage, dignity upheld '; (e) bertih, made through 'digongseng' or fried rice without 
using oil, commonly also referred to by the term ' diondang ', which means marital life, with the same fate ans shares the same pain as ' all for one, and one for all ', and it is also intended as a delicacy for supernatural creatures who witnessed the ceremony while removing the catastrophe; ( $f$ ) henna leaves are finely grounded with a touch of lemon or lime juice, water, rice, yam leaves and gambier), which means that the symbolic harmony and loyalty in marital life, and keep them away from any disaster like the phrase, ' the house creates the pillars to keep disaster '; (g) potpourri, scented flower which is inimitable and added some small scented pandan leaves in order to increase the fragrance, symbolising inner and outer purity, dignity and family's honour II

\section{Social Value}

The social values of 'tepung tawar' according to the informant Syafrial Pasha, SS are that 'the social values of 'tepung tawar' can be seen during the ceremony, that is, those who do 'tepung tawar' includes the family, friends and acquaintances. 'Tepung tawar' is used to pray for both groom and bride long lasting relationship. From what is mentioned just now, social values can be reflected in 'tepung tawar' ceremony, that one cannot live alone without other people's support, so this 'tepung tawar' ceremony will not be able to be completed when there are no one to do the ceremony. In addition, the prayers are then blessed to both the bride and groom to live happily with community and also represent the social value of the community.

\section{Family Values}

Syafrial Pasha, SS explained the value of companionship embedded in the 'Bunga Segar' ceremony that is connected with 'tepung segar' clearly explained the familial values. Therefore, the communities that still practised this activity elaborated the fact that community activities still have positive values. Apart from that, at every 'tepung tawar' ceremony, there will be people that prioritise the newlyweds. This may be a possible notion that 'tepung segar' process instilled many positive values specifically familial values.

\section{Religious Values}

Ali Chan said, "Each Malays has their religion, every religion of the Malays are Muslim and every cultural and customary practices of the Malays are planted with divine elements that reflects religious values which are respected by the local community, If the religious element does not exist in every activity of cultural and customary practices, that means a person is not a Malay and a non-Muslim. Moreover, in the 'tepung tawar' ceremony, elements of religion is very important to be included into the ceremonies as it brings great expectations from all parties for the blessing of both the bride and the groom to beseech God Almighty Allah SWT, nothing can happen without God as is the case with the 'tepung tawar' ceremony.

The benefit of combining elements of divinity and religious values in each customary activities is to improve the spiritual qualities of Malay society especially in the City of Medan, Northern Sumatran Province, Northern Sumatra and to continue maintaining and nurturing every activity of the Malay custom to this day especially the 'tepung tawar' ceremony. 


\section{Cultural Values}

Ali Chan mentions, "tepung tawar' ceremony "is a cultural activity and practice of customs, the activity is certainly based on the background of cultural elements and cultural values. In addition, cultural values can also be viewed through the activities contained in the 'tepung tawar' ceremony such as poetry, the marriage of the Deli Malays in City of Medan, Northern Sumatran Province as well as the 'berzanji' which adds aesthetic value. With the existence of these values, the 'tepung tawar' ceremony is still practised and remain preserved by Deli Malays of Northern Sumatra until today. "

In addition, elements and cultural values which form the basis of activity and customary practice is one of aspects that are able to attract tourist to watch it especially the 'tepung tawar' ceremony. Preserving indigenous culture and activities that can invite tourists may be done by organising cultural exhibitions containing activities featuring traditions found throughout the Indonesia, specifically the Northern Sumatran Region which is particularly rich in Malay culture especially the 'tepung tawar' ceremony. These activities encourages preservation of culture and the Malay tradition from the past to the present.

\section{Conclusion}

From the results of this research, it can be noted that any ceremony conducted by the Deli Malays have their specific meaning and functions. These values describe the patterns of life and the familial system of the Deli Malay community.

The marriage of the Deli Malays in the City of Medan, Northern Sumatran Province, the traditions of the Deli Malay wedding has certainly paved the newlyweds a path and guidance to undergo a marital life as it contains a valuable lesson. Even more so for the Deli Malays in the City of Medan, Northern Sumatran Province to not lose direction or blinded by globalisation that is filled with all manner of foreign cultural influence.

\section{References}

Eriswan. (2012). Islam Dan Budaya Melayu: Dalam Mewujudkan Visi Institut Seni Indonesia (Isi) Padangpanjang. Jurnal Ekspresi Seni, Vol. 14, No. 1, 1-10.

Maqbool, S., Ismail, S. A. M. B. M., Maqbool, S., \& Hassan, S. U. (2018). Effects of Traditional Lecture Method and Multi-Sensory Approach on ELT Learners at Graduate Level. International Journal of Academic Research in Progressive Education and Development, 7(4), 488-505

Morissan. (2013). Teori Komunikasi: Individu Hingga Massa Edisi Pertama. Jakarta: Kencana.

Sinar, T. L. (2005). Adat Budaya Melayu: Jati Diri dan Kepribadian. Sumatera Utara: Forum Komunikasi Antar Lembaga Adat.

Sobur, A. (2004). Semiotika Komunikasi. Bandung: PT Remaja Rosdakarya.

Syahrial, M. T. (2015). Adat Dalam Peradaban Melayu. Laporan Penelitian Program Studi Etnomusikologi Fib Usu Dan Majlis Adat Budaya Melayu Indonesia. Medan. 
INTERNATIONAL JOURNAL OF ACADEMIC RESEARCH IN BUSINESS AND SOCIAL SCIENCES

Vol. 9, No. 11, November, 2019, E-ISSN: 2222-6990 @ 2019 HRMARS

Takari, M., Zaidan, B. S., Fadlin, M. D. (2014). Adat Perkawinan Melayu: Gagasan, Terapan, Fungsi, Dan Kearifannya. Medan. USU Press Art Design, Publishing \& Printing.

Zulfadhli (2018). Determination of Industrial Competitiveness on Manufacturing Industry Growth in Palembang City, International Journal of Academic Research in Accounting, Finance and Management Sciences 8 (3): 238-254 